\title{
RELAP-7 Beta Release: Summary of Capabilities
}

Richard C. Martineau, Hongbin Zhang, and Haihua Zhao

December 2014

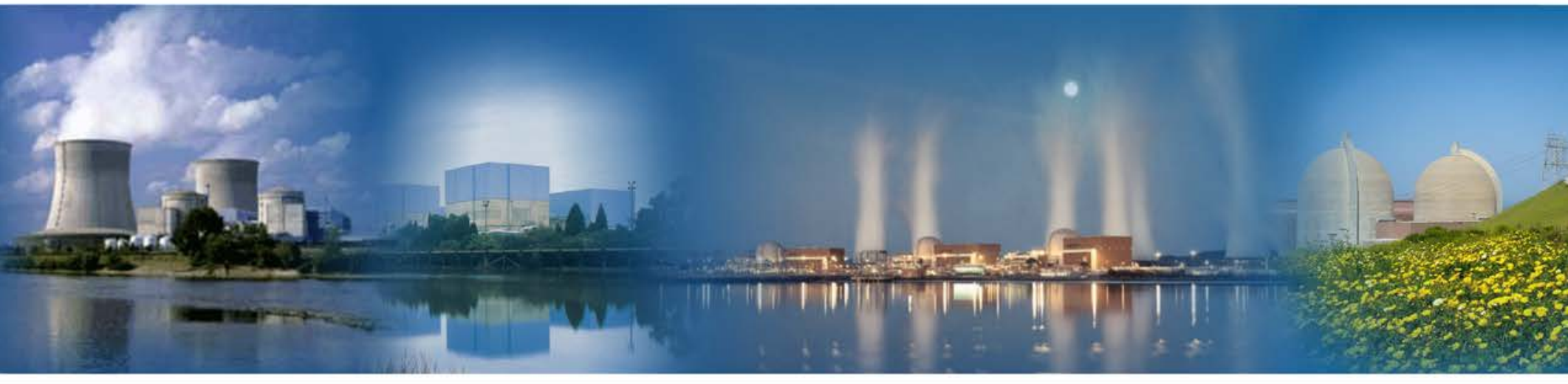

U.S. Department of Energy

Office of Nuclear Energy 


\section{DISCLAIMER}

This information was prepared as an account of work sponsored by an agency of the U.S. Government. Neither the U.S. Government nor any agency thereof, nor any of their employees, makes any warranty, expressed or implied, or assumes any legal liability or responsibility for the accuracy, completeness, or usefulness, of any information, apparatus, product, or process disclosed, or represents that its use would not infringe privately owned rights. References herein to any specific commercial product, process, or service by trade name, trade mark, manufacturer, or otherwise, does not necessarily constitute or imply its endorsement, recommendation, or favoring by the U.S. Government or any agency thereof. The views and opinions of authors expressed herein do not necessarily state or reflect those of the U.S. Government or any agency thereof. 


\title{
RELAP-7 Beta Release: Summary of Capabilities
}

\author{
Richard C. Martineau, Hongbin Zhang, and Haihua Zhao
}

December 2014

Idaho National Laboratory Idaho Falls, Idaho 83415

http://www.inl.gov

Prepared for the

U.S. Department of Energy

Office of Nuclear Energy

Under DOE Idaho Operations Office

Contract DE-AC07-05ID14517 


\section{INTRODUCTION}

RELAP-7 is a nuclear systems safety analysis code being developed at the Idaho National Laboratory (INL). Building upon the decades of software development at the INL, we began the development of RELAP-7 in 2011 to support the Risk Informed Safety Margins Characterization (RISMC) Pathway. As part of this development, the first lines of RELAP-7 code were committed to the software revision control repository on November 7th, 2011. The overall design goal of RELAP-7 is to take advantage of the previous thirty years of advancements in computer architecture, software design, numerical methods, and physical models in order to provide capabilities needed for the RISMC methodology and to support nuclear power safety analysis.

RELAP-7 is built using the INL's modern scientific software development framework, MOOSE (Multi-physics Object Oriented Simulation Environment). MOOSE provides improved numerical calculations (including higher-order integration in both space and time, yielding converged second-order accuracy). The RELAP-7 code structure is based on multiple physical component models such as pipes, junctions, pumps, etc. Each component can have options for different fluid models such as single- and two-phase flow. This component-based and physics-based software architecture allows RELAP-7 to adopt different physical models for different applications. A relatively new two-phase hydrodynamic model, termed the "7-Equation model" for two phasic pressures, velocities, energies, and volumetric fraction, is incorporated into RELAP-7 for liquid-gas (water-steam) flows. This new model allows second-order integration because it is well-posed, which will reduce the numerical error associated with traditional systems analysis codes.

In this paper, we provide a RELAP-7 capability list describing analysis features, range of applicability, and reactor components that will be available for the December 15th, 2014 beta release of the software.

\section{Summary of RELAP-7 Capabilities}

1. Analysis Capabilities:

1) All-speed, all-fluid (vapor-liquid, gas, liquid metal) flow algorithm - agnostic of reactor concept (coolant types). Specific hydrodynamic models include single-phase flow (liquid water, liquid metal, and single component gas flow), homogeneous equilibrium twophase flow (HEM), and 7-Equation two-phase flow with simple closures.

2) Point kinetics model for simple neutronics analysis.

3) Multi-group radiative diffusion for assembly-homogenized calculations when coupled through the multi-scale radiation transport application, Rattlesnake.

4) One and two-dimensional core heat structures strongly coupled with coolant fluids, or conjugate heat transfer (CHT). Core heat structures are based upon fuel-gap-clad substructures.

5) Fuels-performance-informed core heat structures through coupling with the BISON fuels performance application. This coupling capability enables fuels performance information to be provided directly to the core heat structures for fuel state evolution (burnup, depletion, and decay heat), pellet-cladding interaction (gap closures), thermal property evolution, and clad/centerline fuel temperatures.

6) Separate Argonne developed version of RELAP-7 narrowly focused upon sodium fast reactors, sodium coolant, and fast spectrum point kinetics.

2. Range of Applicability:

1) Single-phase steady state and transient analysis for PWR applications (note that the steam generator model for a PWR will not be available) using HEM.

2) BWR steady state and transient analysis (including SBO) using HEM. 
3) BWR steady state and transient analysis (including SBO) using the 7-equation two-phase flow model for the reactor core and HEM for the balance of the plant.

\section{Equation of State/Properties:}

1) Ideal gas equation of state for single-component gas (helium, nitrogen, etc.).

2) Stiffened gas equation of state for single-phase liquid water and simplified water steam mixtures.

3) Linearized equation of state for general applications such as single-phase water and sodium.

4) IAPWS-95 steam/water properties.

\section{Available Components:}

The table below shows the available components and their brief description.

\begin{tabular}{|c|c|}
\hline $\begin{array}{l}\text { RELAP-7 } \\
\text { Component ID }\end{array}$ & Description \\
\hline Pipe & $\begin{array}{l}\text { 1-D fluid flow within solid structure with wall friction and specified } \\
\text { wall temperature or wall heat flux. }\end{array}$ \\
\hline PipeWithHeatStructure & $\begin{array}{l}\text { 1-D fluid flow associated with a 1-D/2-D solid heat structure, } \\
\text { including fluid flow, solid heat conduction with different boundary } \\
\text { conditions. }\end{array}$ \\
\hline CoreChannel & $\begin{array}{l}\text { Simulating reactor flow channel and fuel rod, including 1-D flow and } \\
1-\mathrm{D} / 2-\mathrm{D} \text { fuel rod heat conduction. }\end{array}$ \\
\hline Subchannel & Simulating 3-D single- \\
\hline HeatExchanger & Heat exchanger model, including single-phase and two- \\
\hline HeatExchanger & Heat exchanger model, including single-phase and two- \\
\hline HeatExchanger & Heat exchanger model, including single-phase and two- \\
\hline Branch & $\begin{array}{l}\text { Multiple in and out 0-D junction for single-phase and two-phase flow } \\
\text { HEM. }\end{array}$ \\
\hline Valve & $\begin{array}{l}\text { One in and one out junction with controlled flow area and resistance to } \\
\text { simulate valve open / close action for low-speed single phase flow. }\end{array}$ \\
\hline CompressibleValve & $\begin{array}{l}\text { Simulate valve open and close behavior for compressible flow, } \\
\text { including choking for single-phase gas; can be used as safety relief } \\
\text { valve (SRV). }\end{array}$ \\
\hline CheckValve & $\begin{array}{l}\text { Simulate the check valve behavior with the form loss calculated by the } \\
\text { abrupt area change model }\end{array}$ \\
\hline Pump & $\begin{array}{l}\text { A junction model with momentum source connecting two } \\
\text { components. }\end{array}$ \\
\hline PointKinetics & 0-D neutron kinetics model. \\
\hline SeparatorDryer & $\begin{array}{l}\text { Separating steam and water with mechanical methods, } 1 \text { in and } 2 \text { out } \\
\text { branches with volume. }\end{array}$ \\
\hline Downcomer & 0-D volume to mix different streams of water/steam. \\
\hline WetWell & 0-D volume to simulate BWR suppression pool and its gas space. \\
\hline Reactor & $\begin{array}{l}\text { A virtual component that allows users to input time dependent thermal } \\
\text { power for CoreChannel model. }\end{array}$ \\
\hline Turbine & $\begin{array}{l}\text { Simulate BWR Reactor Core Isolation Cooling (RCIC) turbine which } \\
\text { drives the RCIC pump through a common shaft, } 0 \text {-D junction. }\end{array}$ \\
\hline Pressurizer & Simulate pressurizer dynamic behaviors with a 3-zone model. \\
\hline
\end{tabular}




\section{Target Users Community for the release}

Currently, RELAP-7 code is still undergoing development. The primary objective of the December 2014 beta release is to get feedback and suggestions for improvement on usability and applicability from the user community. Therefore, this beta release will be limited to a select set of users who are experienced in developing and using reactorsystems safety analysis codes such as RELAP5, TRAC, and TRACE. This initial release will not be made available to the general user community.

6. Supporting Documents

1) An updated RELAP-7 Theory Manual will be available with the Beta release.

2) A draft RELAP-7 Users Guide will be available with the Beta release. The users guide will contain multiple example problems from simple single pipe flow to complicated plant models to help users to learn how to setup problems and to use the RELAP-7 code.

\section{Details of Capabilities}

Additional details for the components that will be available in the December 2014 beta release can be found in the following table. 


\begin{tabular}{|c|c|c|c|c|c|c|c|c|}
\hline \multirow[b]{2}{*}{ RELAP-7 Component } & \multicolumn{3}{|c|}{ Dimensionality } & \multicolumn{3}{|c|}{ Hydrodynamic Model } & \multicolumn{2}{|c|}{$\begin{array}{c}\text { Suitable for } \\
\text { conditions in... }\end{array}$} \\
\hline & $0 \mathrm{D}$ & $1 \mathrm{D}$ & $2 \mathrm{D} / 3 \mathrm{D}$ & $\begin{array}{l}\text { Single } \\
\text { Phase }\end{array}$ & $\begin{array}{l}\text { Two } \\
\text { Phase } \\
\text { HEM }\end{array}$ & $\begin{array}{l}\text { Two } \\
\text { Phase } \\
\text { 7-Eq. }\end{array}$ & PWR & BWR \\
\hline Pipe & & - & & - & - & - & - & घ \\
\hline PipeWithHeatStructure & & - & - & - & - & घ & ш & - \\
\hline CoreChannel & & - & - & - & - & - & - & - \\
\hline Subchannel & & & - & - & & & - & \\
\hline HeatExchanger & & घ & - & घ & - & & घ & घ \\
\hline TimeDependentVolume & - & & & - & - & - & - & घ \\
\hline TimeDependentMassFlowRate & - & & & - & - & - & - & घ \\
\hline Branch & - & & & - & - & & - & घ \\
\hline Valve & - & & & - & & & ш & घ \\
\hline CompressibleValve & - & & & - & & & घ & घ \\
\hline CheckValve & - & & & - & & & - & - \\
\hline Pump & - & & & - & & & - & घ \\
\hline PointKinetics & - & & & & & & - & घ \\
\hline SeparatorDryer & - & & & & - & & & घ \\
\hline Downcomer & - & & & & - & & & घ \\
\hline WetWell & - & & & - & - & & & घ \\
\hline Reactor & - & & & & & & - & घ \\
\hline Turbine & - & & & - & & & ш & घ \\
\hline Pressurizer & - & & & & - & & - & \\
\hline
\end{tabular}

